\title{
AN AFRICAN FETISH
}

THE Government of Southern Nigeria having received information that a Juju, or Fetish House, existed in the Andoni Country, where human sacrifice and cannibalism were said to be practised, it lately became my duty to take the necessary measures to put an end to this Society, which for so long had exercised such a baneful influence upon the surrounding villages.

This Juju, known to the Natives as "Oyobulo," existed at the town of Allabia, situated up a narrow tortuous Creek in the Mangrove swamp, and consequently was secure from observation; indeed, until quite recently the existence of this place was not known to Europeans; while the Chiefs and people in touch with the Government, refrained from giving any information-possibly through superstitious fears.

The Chiefs of Bonny and Opobo having more or less nominal control over the Andonis, I summoned representatives from these districts to meet me at Allabia, and held a meeting there at which most of the Andoni villages were also represented.

I expressed the determination of the Government to put an end to human sacrifice and cannibalism; and insisted that all Jujus having connection with these terrible customs, must be destroyed. I called the attention of the meeting to the fact that I had come there unarmed and unaccompanied by soldiers (thus giving them the opportunity of obeying the behests of the Government quietly, and avoiding the necessity of using force), and that the Juju House must be destroyed at once or strong measures would be resorted to. After considerable demur, the principal Andoni Chief led 
the way to the centre of the village where the Juju was situated.

Although I had expected to find some display of human remains the sight exceeded my expectations, the verandah posts, gable ends, and walls of the Juju House being completely covered with human skulls : most of these ghastly objects were discoloured with age, but many were comparatively fresh, a conclusive proof that until quite recently human sacrifice had been practised in the town.

Before destroying the place, I counted the skulls, which I found to number considerably over 2,000, an awful example of the waste of human life that takes place where these heathen customs exist. The people present were most reluctant to take part in the destruction of the Juju and eventually I had to set fire to the house myself.

Before leaving, I was told of the existence of another "Juju" some little distance away in the bush, but could get no definite information or anyone to guide me to the place, and as the Natives by this time were very much excited, I deemed it advisable to leave the matter for another occasion.

Three days later I returned to Allabia accompanied by a small Escort of Police, and after bringing pressure to bear upon the head Chief and Juju priest I was conducted to the bush Juju. Embarking in small canoes we paddled for some distance up a narrow and tortuous channel in the Mangrove swamp, landing finally in a gloomy grove, a narrow pathway leading to the place we were in quest of. This proved to be a low thatched hut closed about with screens of palm leaves, under which it was necessary to crawl, and which, with the surrounding dense scrub and rank grass, would effectually screen the Juju priests from observation when performing their terrible rites. In this hut were found many skulls and bones of victims, and all the paraphernalia used in the Juju ceremonies, consisting of ivory tusks, an ivory horn with five human skulls attached, the swearingpot, emitting a frightful stench when broken, copper spears and swords, a bronze image of an ljo man from the lower Niger, a stool decorated with the heads of dogs, goats, and 
pigs, sacrificial pots, copper coils, large manillas and other old forms of Native currency, and many other objects of interest which are shown in the photographs illustrating this article.

One of the most interesting finds was a ship's bell, which evidently at one time belonged to an old Dutch Slaverbeing inscribed OTTO BAKKER ROTTERDAMM 1757.

I am indebted to a native of the country for the following information regarding the customs and ideas associated with Juju worship, and with the articles found at Andoni.

The Andoni Juju House.

It is needful to make certain statements as a preface before remarking on the different articles obtained from this great Juju, or Fetish House, in order to put us in touch with the ideas they impart.

I. The knowledge of the Supreme God is to be found amongst all Africans wherever you go, as a Creator and a good and kind Being.

They worship idols to protect them against the evil one, whose existence they are also aware of, and whose power they dread;-and charms are hung up in doorways of houses to drive away this influence or to deprive it of its power.

To show that there is a marked distinction made between God, and gods or idols employed as helpers or mediators, we notice the different names by which they are called:e.g.

In Yoruba language Olorun is the God of Heaven.

In Yoruba language Orisa is the name of a god or idol.

In Bonny language Tamuno is the God of Heaven.

In Bonny language Oru is the name of a god or idol.

In Ibo language Tsineke is the God of Heaven.

In Ibo language Abarra is the name of a god or idol.

2. The idea that without blood there can be no remission of sins, exists strongly in the minds of the heathen, hence the slaying of goats, sheep and fowls and the sprinkling of 
[To face page 412.

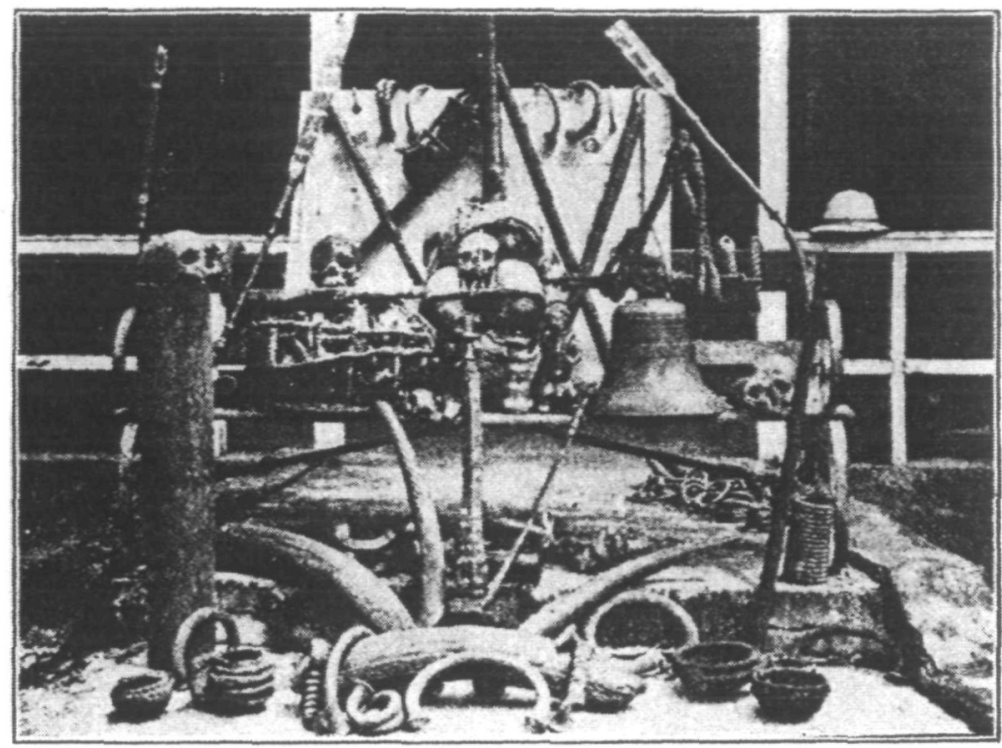

Fetish Objects in the Anjoni Juju House.

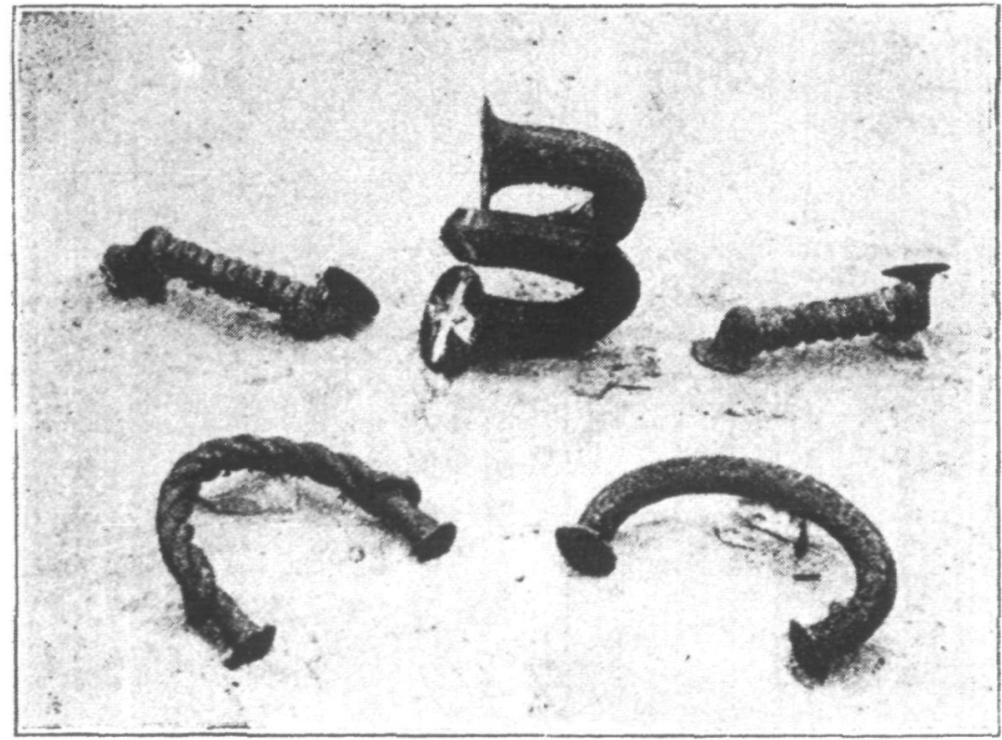

Charms (Manillas) from Andoni Juju House. 
their blood on the altars in sacrifices, and on the foreheads of the worshippers, as a cleansing away of evil and procuring of good or of blessing.

The Juju priests and their attendants fed on the goats and fowls offered, after the blood was made use of.

3. To impress the worshippers with the idea of sacredness, the entrance into the shrine was made as dreadful as possible.

To enter Andoni Juju house, you would have to pass through a dismal grove, and along a narrow pathway leading into an open space where skulls and bones of victims lay about, and you saw in front of you a shrine of palm leaves guarding the Juju house itself. On the entrance were hung charms of every description.

In the inner Court were ivory tusks, embellished with camwood dye and chalk, pots containing manillas, then human skulls with which both interior and exterior of the Juju house were lined, interspersed with the heads of sheep, goats and dogs; and on the inner shelves, carved images of different sizes vying with each other in rudeness; besides, at every corner, a small pot containing earth with feathers, \&c., stuck in.

Having now some idea of what a Juju house is, we will state the meaning of some of the objects of worship found there.

I. The ivory tusks have their different uses.

The large ones were the horns of the altar, and any transgressor escaping without being caught by the way, and managing to enter the Juju house and hold the tusks of ivory, could not be touched by anyone, however heinous his crime, as he had held the ivory Juju and was free; but the rite of burial was denied that person, and on his death the corpse was thrown into the river.

If however the criminal wished, he gave himself up altogether to Juju, stayed to help in performing duties in the Juju house, and when he died Juju buried him.

The tusks with holes in the convex side were usually blown when human sacrifices were offered.

II. The charms (manillas) tied together in bunches are called Igu-duogu; these were hung over the passage to ward 
off evil; they were sent on receipt of good payment to houses disturbed by evil spirits.

III. The long carved sticks (like walking sticks) are made of a certain wood called ODIRI, these sticks painted with chalk and camwood were given to women in pregnancy as a protective wand.

This same wood is also used in marriage ceremonies, being bought by the parties to be married from the Juju priests, and supplied from the fetish grove.

The ceremony is thus described :-

Two stout sticks of ODIRI about 4 feet in height and sharpened at the bottom are driven into the ground in a corner of the house of the bridegroom by the priests, the sticks are then called by the name TsE. This rite is performed on the day the bride is brought into the house; the man and the woman place their feet on the sticks while a goat is killed and the blood sprinkled on their feet. After this ceremony death alone can utterly dissolve the marriage tie.

If the woman afterwards leaves the rightful husband, he claims all the children, born of her (though they may be by Chiefs and Kings), as his property, and they must be delivered up.

When the woman dies she cannot be buried except by the original husband, another person undertaking to do so incurring great punishment, and in the olden days, death.

IV. The large twisted manilla called Orbor was of great importance in this Andoni and other Juju houses, and came prominently into use by women in a state of pregnancy at three different stages, viz. :- at the second, sixth, and ninth months.

Offerings of eggs and manillas were brought by the woman at the first stage, and whilst invocation was being made by the priest, she laid hold of the large twisted manilla, (or copper coil). At the second stage offerings of whitefeathered hens and manillas were brought, and at the last stage white cocks were killed.

The original article sent to England as sample of this twisted manilla was a "ram's horn" which is emblematic 
of strength, and the purpose of laying the hands on this ram's horn was to excite the passions, and impart strength to the female who was expecting a child.

The long twisted copper articles were held by young women at a particular dance called OYOBuLo, all of which suggested procreation of children.

V. In the inner Juju house would be a pot like the one shown in the photograph, but larger, called the swearingpot. It was filled with chips of wood considered poisonous, thorns and thistles were thrown in and made into a decoction which fermented and emitted a most horrible stench.

The outside of the pot was made up with palm ropes on which were tied human bones, also those of fierce animals and reptiles, as leopards, snakes, \&c., with feathers of birds of prey and other savage ornamentations; the whole being chalked and dyed to present a fearful appearance.

This "swearing-pot" was said to have the power of finding out witches, poisoners, evil intentions, and such like and whenever a person was suspected, the suspecting party or parties, paid a large sum of money to the priests and the pot was taken to the town or village at dead of night, and the person or persons suspected, made to jump over it; the innocent ones escaping injury or ill effect, while the guilty were expected to die within a stated time.

This swearing-pot was peculiar to the Andoni Juju house as being the sttongest and most efficacious in finding out guilty parties and killing them; and as a consequence it was much sought after by the neighbouring places, and greatly reverenced by the priests.

Those who could not afford to take it to their village, went to Andoni to consult it, and learn who were their enemies.

It is said that to look into that pot, or to touch it, except for the priests, was nothing short of death.

VI. The swords, spears, \&c., were worshipped as emblems of war and invoked for success before setting out on an expedition.

In the same way paddles were invoked for success and blessing in trade.

VII. The heads of the victims were usually made into soup 
and consumed by the priests, the skulls being afterwards placed in the Juju house.

The skulls would be of those suspected of witchcraft, and prisoners taken in war, or slaves, slain in the annual sacrifice to the gods.

VIII. There was an historical drum in the Andoni Juju house, made entirely of human skin and only beaten when the executioner struck off the head of a victim. This drum was usually hung up on a very high post in the inner Court, and was doubtless burnt up with the house.

A. A. WhITEHOUSE 